\title{
Women's work choices in Kenya: the role of social institutions and household gender attitudes
}

Article

Accepted Version

De Giusti, G. and Kambhampati, U. (2016) Women's work choices in Kenya: the role of social institutions and household gender attitudes. Feminist Economics, 22 (2). pp. 87-113. ISSN 1466-4372 doi:

https://doi.org/10.1080/13545701.2015.1115531 Available at https://centaur.reading.ac.uk/56829/

It is advisable to refer to the publisher's version if you intend to cite from the work. See Guidance on citing.

To link to this article DOI: http://dx.doi.org/10.1080/13545701.2015.1115531

Publisher: Taylor \& Francis

All outputs in CentAUR are protected by Intellectual Property Rights law, including copyright law. Copyright and IPR is retained by the creators or other copyright holders. Terms and conditions for use of this material are defined in the End User Agreement.

www.reading.ac.uk/centaur 
Central Archive at the University of Reading

Reading's research outputs online 


\title{
WOMEN’s Work ChOICES In Kenya: The Role of Social Institutions
}

\section{AND HOUSEHOLD GENDER ATTITUDES}

Giovanna De Giusti and Uma Sarada Kambhampati

\begin{abstract}
This study considers the factors that influence women's work behavior in Kenya. In particular, it examines whether gender attitudes and certain types of social institutions influence the probability of employment or type of employment for women. Using data from the Demographic and Health Survey of 2008-9, we find that religion and ethnicity are significant determinants of women's employment in Kenya. While personal experience of female genital mutilation is insignificant, spousal age and education differences, as well as marital status (which reflect attitudes both in women's natal and marital families), are significant determinants of women's employment choices.
\end{abstract}

\section{KEYWORDS}

Women's labor force participation, institutions, intra-household bargaining 


\section{HEADER: WOMEN'S WORK CHOICES IN KENYA}

\section{INTRODUCTION}

It is increasingly accepted that women are a country's "hidden resource. Investing in women and girls now will increase productivity in this generation and will promote sustainable growth, peace, and better health for the next generation" (British Council 2012: p.i]). In this context, women's employment is crucial because it can be harnessed for economic growth and family prosperity, and also because it is seen as helpful in empowering women and thereby improving family welfare. Increasing women's work opportunities translates into better economic and welfare outcomes for women (Kivan Munshi and Mark Rosenzweig 2006; Nancy Qian 2008; Robert T. Jensen 2010), and women's economic empowerment can improve household welfare (Esther Duflo 2012).

In this paper, we consider factors that influence women's employment in Kenya. In particular, we are concerned with the role of traditional gender attitudes and sociocultural institutions in determining women's labor force participation. Not surprisingly, these attitudes are themselves endogenous to whether women undertake work. In particular, it is often acknowledged that certain types of jobs (those in the modern sector of the economy or those that take the woman outside of the home) are more likely to engender women's autonomy.

We attempt to address this potential reverse causality by using proxies for these attitudes before the woman begins work. One way to do this is to consider the impact of sociocultural institutions, such as religion and ethnicity, which are likely to be exogenous and 
capture a reduced form effect of such attitudes on women's employment. ${ }^{1}$ A second approach is to consider gender attitudes more specifically through the inclusion of variables reflecting the circumstances in which the woman was born and into which she has married. Such variables include whether the woman was circumcised, whether she is in a polygynous relationship, her age and education relative to her husband, and her age at first marriage.

To the extent that these proxies are not completely exogenous, our results need to be interpreted as correlations rather than as identifying causality. We find that even after controlling for a range of family and sociodemographic factors, religion and ethnicity are significantly correlated with women's employment prospects, particularly with restricting women's work outside the household. Among the more specific household gender attitude variables, we find that polygyny and the woman's age and education gap relative to her husband are especially significant. Women who are in polygynous unions work more, though they are mostly self-employed. Additionally, closeness in age and education between the spouses is associated with an increase in the probability of women undertaking paid work, particularly outside of the household.

This paper makes a contribution to the literature on women's labor force participation in three ways. First, very few papers look at the impact of institutions on labor market behavior, especially in developing countries. However, in an analysis of whether women undertake paid work and, if so, the kinds of jobs they do, the impact of these institutions is likely to be key. This is because, by framing gender-relevant meanings and defining gender roles, they influence the distribution of power between men and women in the private sphere of the family, in the economic sphere, and in public life, thereby shaping women's economic and social opportunities (Boris Branisa, Stephan Klasen, and Maria Ziegler 2010). This paper looks at the dense network of sociocultural institutions that exists in Kenya but also considers 
the extent to which the gender norms underlying these religious and ethnic institutions are important in influencing women's labor force participation.

Second, we have identified proxies for initial patriarchal attitudes which, in the context of Kenya, attempt to avoid the problem of reverse causality from employment back to gender attitudes. We do this by appealing to the fact that women in Kenya start paid work late and marry early indicating that in most cases, they will be married before their work experience could influence their marital choices. While there is a possibility that women might anticipate their employment choices in choosing whom to marry and when, this seems on average unlikely when the vast majority of women are employed in 'survival' businesses and family employment (see Aderanti Adepoju and Christine Oppong [1994]; Martha Chen, Joann Vanek, Francie Lund, James Heintz, Renana Jhabvals, and Christine Bonner [2005]; and Marty Chen [2008]). In addition, the slow rates of change of social institutions and gender attitudes are likely to further limit reverse causality.

It is also possible that a woman's choices are influenced more by her community's attitude than by her own personal views. To account for this, we analyze the impact of religion and ethnicity on the labor participation decision. While employment which exposes women to liberal attitudes outside the home, might erode patriarchal attitudes over time, this is unlikely in the case of our sample for a number of reasons. First, figures indicate that women's employment in Kenya is mostly within the family or is self-employment. Such employment is unlikely to lead to exposure to liberal values (International Labor Organization [ILO] 2008; Anderson and Easwaran 2009). ${ }^{2}$ Second, such changes in attitude take time (Alberto Bisin and Thierry Verdier 2000; Herbert Gintis 2001), and in our sample, we see that most women are actually married before they begin paid work. In this context, the proxies we have chosen are likely to remain exogenous. 
Third, we distinguish between various work options - work for family, work for outsiders, and self-employment - each of which we expect to be differently affected by these social and gender institutions. In particular, while work for family may be encouraged and self-employment tolerated, work for outsiders may be taboo (Claudia Goldin [1994]; Sarah Salway, Shahana Rahman, and Sonia Jesmin [2003]; for an overview on women's work in Sub-Saharan Africa, see Chen [2008]).

Salway, Rahman, and Jesmin (2003) find that, despite women's work being necessitated by poverty in Dhaka, both sociocultural constraints and persistent social stigma limit women's employment. In this regard, Goldin (1994) claims that social norms may limit the ability of women to accept paid employment (especially in manual jobs), and these norms appear to apply to wives but not to unmarried women. Existing literature, for example, argues that polygyny enables the husband to control the labor power of his wives, leading to an increased probability of women working for their families or for themselves rather than for outside employers (Esther Boserup 1970; Hanan G. Jacoby 1995; Salway, Rahman, and Jesmin 2003). In Bangladesh, however, Salway, Rahman, and Jesmin (2003) observe that women often give up work after marriage because their husband's demand it or because they have restricted time. By analyzing work for the family, for outsiders, and self-employment separately, we are able to identify the effects of norms and institutions on each of these work options.

Before proceeding further, a caveat is in order. Despite our efforts to deal with the issue of endogeneity, our solutions are necessarily second best. Our estimations attempt to deal with reverse causality using a variety of proxies, which we argue are likely to be exogenous, though it is hard to establish this beyond a doubt. Given the nature of the model being estimated (with a discrete dependent variable) and the difficulty of finding an appropriate instrument, it has not been possible to estimate an instrumental variable model. 


\section{LITERATURE REVIEW}

While the factors influencing women's employment have been analyzed by many authors (Nadia Steiber and Barbara Haas 2012), few studies have looked at the impact of sociocultural institutions on women's labor force participation. To the extent that this issue has been studied, most researchers have concentrated on sociocultural norms in Western market economies (Nicole M. Fortin 2005; Lídia Farré and Francis Vella 2013; Raquel Fernández 2013). Yet, evidence and reports by the International Labour Organisation (ILO 2008) and United Nations Development Fund for Women (Chen et al. 2005) show that in many developing countries gendered norms (relating to women's work and men's work) shape the labor market and the position of women within it.

Christian Morisson and Johannes P. Jutting (2005), in analyzing this issue across developing countries, consider the impact of a range of economic and non-economic variables on the proportion of actively employed women in each country. Analyzing the impact of gender institutions (including polygyny, female genital mutilations, early marriage, authority over children, right to inherit from the husband, right of ownership, and freedom of movement and dress) on women's employment, they find evidence that social institutions are a major determinant of women's employment. This study, however, aggregates at the level of countries and is therefore unable to comment on differences across households and also intrahousehold relationships, which might influence employment status. It is worth noting (as is discussed further below) that employment will also influence a woman's status by shifting her income share relative to that of her husband's, thereby changing the intrahousehold bargaining power (Kaushik Basu 2006). 
Fortin (2005) estimates the impact of gender attitudes on the gender gap in labor force participation and earnings across twenty-five Organisation for Economic Co-operation and Development (OECD) countries. She finds that perceptions of men as breadwinners and women as homemakers are strongly and positively associated with the gender gap in employment rates and earnings across countries. While Fortin concentrates on the supply side of this decision, it is worth noting that gender role attitudes are also likely to influence an employer's decisions about whom to hire, to which positions, and how much to pay them. Fortin also warns that many of her results "should be more precisely referred to as partial correlations, rather than causal factors" (420).

Diane Elson (1999) distinguishes between labor force participation (including all kinds of work done by women) and labor market participation (which excludes unpaid family workers who do not enter the labor market). She argues that instead of being gender neutral, labor markets are the "bearers of gender"[please insert page number], and therefore carry social stereotypes about what is men's work and what should be done by women. This distinction is crucial to our analysis as we distinguish between work for family, work for outsiders, and self-employment.

Basu (2006) articulates the endogeneity inherent in women's labor force participation when he argues that a woman's work activity is an outcome of her existing bargaining power but her say in household matters (autonomy) is, in turn, determined by her work. Thus, there is likely to be two-way causality between autonomy and labor participation so that the balance of power within the household influences household choices but these choices can in turn affect the household's balance of power. This endogeneity makes it difficult to use direct autonomy measures (emotional, physical, and decision-making autonomy, for instance) of the kind that are made available in the Demographic and Health Survey (DHS) datasets and have often been used in the literature (Michelle J. Hindin 2000; Shireen J. Jejeebhoy 2002; Farré 
and Vella 2013). The inclusion of age at first marriage, age, and education gaps relative to the husband in our estimation help to capture these intra-household dynamics in our model.

\section{THE KENYAN CONTEXT}

Kenya is a good country in which to analyze the impact of social institutions on employment because it contains a number of religions and over seventy ethnicities. Kenya is a predominantly Christian country, with a significant number of Muslims and a small minority belonging to other religions (such as Hindus) and traditional beliefs (see Table 1). Sixty-two percent of the women in our sample are Protestant Christian; while 19 percent are Catholics and 15 percent Muslim. Of the Protestant Christian women in our sample, 26 percent are not employed, while 23 percent work for outsiders. These values are similar for the Roman Catholic women (30 and 22 percent, respectively). The highest percentage of women not employed is in the Muslim group (64 percent), and in the "other religions" category (68 percent), which also exhibits the lowest percentage of women working for outsiders (7 percent).

(Table 1 here)

As Table 1 shows, our sample is spread across twelve distinct ethnic groups (including a "miscellaneous" category). The largest ethnic group in our sample is the Kikuyus (19 percent of women), followed by Luhyas (14.6 percent of women) and Luos (12.6 percent of women). Previous studies indicate that the Somali and Masai groups are the most traditional as far as women's roles are concerned (Hodgson 2000)[please add Hodgson to the references list]. This is confirmed by our data, which show that 80 percent of Somali and 60 percent of Masai women in our sample are not employed. In contrast, amongst the Embu and Kisii, less than 
20 percent of women are not employed. Embu women, as well as Kikuyu, Kamba, Meru, and Taita/Taveta women, are more likely to work for outsiders. Self-employment is most common among the Kisii. Including ethnicity in our model will help to pick up the effect of all norms that are not explicitly included in our model. In this sense, ethnicity is a residual catchall variable for sociocultural institutions.

\section{RESEARCH QUESTIONS}

Our aim in this paper is to consider the impact that social institutions have on the probability of paid work for women, as well as on the type of work women do. In this context, we include ethnicity and religion as a set of formal institutions that might encompass society's attitudes toward women's employment and gender attitudes as a set of informal institutions that more specifically influence women's role in society.

There are a number of social institutions that prescribe either formally or informally what can and cannot be done by various agents within societies. Such norms could influence the gendered division of labor within the home (housework and childcare being seen as women's responsibilities, for instance), the gender division of labor outside the home (certain jobs not being open to women, for example), or the acceptability of women working outside the home (Bina Agarwal 1997), as well as the demand for women in the labor market. Such norms might, for instance, be so pervasive that women do not feel able to work outside the home and employers are also less willing to employ women. Since this would influence one of the three labor market options that we test - employment outside the home - we might expect more women to be employed within the family or to become self-employed. Thus, while such norms might influence women's labor market participation (Elson 1999), they are 
less likely to affect labor force participation. Separating out the type of paid work done by women (work for family, outsiders, and self) will enable us to capture this.

\section{METHODOLOGY}

To address the research question, we estimate two models - first, the factors determining whether women are employed and, second, the factors influencing the kinds of work women do. These models are estimated across two samples - the sample including all women between 21-49 years of age, and a sample of married women. We do this for two reasons. First, it is likely that married women might have different constraints on, or motivations for, their behavior than women who are single. In particular, it would be informative to capture the effect of norms in their husband's family. Second, there are also intrahousehold bargaining issues that are likely to influence the married woman's employment status. These differences in bargaining power are proxied by variables such as relative age, relative education of the partners, or even age at first marriage or type of marriage (monogyny, polygyny etc.), which are included in the model estimated on married women alone.

\section{Modeling whether women are employed}

Our definition of work in this paper includes all paid and unpaid work done by women: in the family, for outsiders, and self-employment (work_status). Work_status is equal to 1 if the woman is in any of these three categories and is equal to 0 if she is not. Since this is a binary decision, we estimate the model using probit methodology. This labor force participation of the woman $i$, is modeled as follows: 


$$
\begin{aligned}
\text { Work_Status }_{i} & =\alpha_{0}+\alpha_{1} X_{1}+\alpha_{2} X_{2}+\alpha_{3} X_{3}+\alpha_{4} X_{4} \\
& +\alpha_{5} X_{5}+\varepsilon_{i}
\end{aligned}
$$

Where $X_{1}$ includes individual characteristics (such as age, education, marital status), ${ }^{3} X_{2}$ is geographic characteristics (type of place); $X_{3}$ includes household characteristics (household size, presence of children, presence of elders, and ownership of assets). In addition, we include $X_{4}$ (social institutions such as religion and ethnicity), and $X_{5}$, which includes measures of household gender attitudes (a woman's experience of female genital mutilation and marital status). In the sample of married women, we also include variables that reflect the woman's position relative to her husband (her age and education relative to her husband).

\section{Type of work done by women}

To analyze the type of work women perform (work_type), we model four labor market options: not participating in the labor market (coded 0); working in a family farm or enterprise (coded 1); working for an outsider (coded 2); and working as a self-employed individual (coded 3). Since these choices are discrete and cannot be ranked, we model them using a multinomial logit methodology. Thus, work_type is modeled as:

$$
\begin{aligned}
\text { Work_Type }_{i}= & \alpha_{0}+\alpha_{1} X_{1}+\alpha_{2} X_{2}+\alpha_{3} X_{3}+\alpha_{4} X_{4} \\
& +\alpha_{5} X_{5}+\varepsilon_{i}
\end{aligned}
$$


Within the estimation, nonworking (0) is considered as the base category, implying that the results of each equation in a set have to be interpreted relative to this category.

\section{DATA}

Our data are from the Kenyan DHS, 2008-9. The DHSs collect nationally representative data on demographic and health indicators for individuals in the reproductive age group and their families. This dataset provides comprehensive information on women's education, employment status and occupation, marital status, sexual activity, fertility preferences, and so forth. The 2008-9 DHS for Kenya collected information on demographic and health issues from a sample of 8,444 women ages 15 to 49 . For the purpose of our analysis, only women between 21-49 years old have been included in our sample. The lower limit was determined by the fact that 76 percent of respondents aged 15 to 20 years were not employed. Thus, our sample includes 6,273 women.

As shown in Table A2 of the supplemental online Appendix ${ }^{4}$ the average woman in our sample is 32 years old, married, and has completed primary school. Of the women in our sample, 56.8 percent were employed. Women were more likely to be self-employed ( 42.5 percent) or to stay at home and do household chores (33.2 percent), rather than work for external employers (19.8 percent), or for a family member (4.5 percent). There is some discussion in the literature regarding whether the categories "not working" and "working for a family member" really are separable (Elson 1999; Morrisson and Jutting 2005), especially when the work for a family member is unpaid. To start with, it is likely that different women may interpret the same work differently. Equally, work for the family is less likely to have an impact on the autonomy of the woman and the kinds of decisions she makes. We have 
therefore separated out four categories with the caveat that there might be fuzziness between not working and working for a family member. To the extent that women who are classified as "not working" are actually working for a family member, it might underestimate the level of employment among women and bias the coefficients of the "working for family" option to look more like the "not working" category.

\section{Empirical estimation}

Both of our models - the probability of work (Model 1) and the type of work (Model 2) include a range of controls common in studies of this kind including the age of the woman, her education level, whether she lives in a rural or urban region, size of household, number of children of different ages, dependency ratio (household members over 60 years old), whether the woman has moved in recent years, and land and house ownership. These variables control for family life-cycle, the presence of dependents, and the availability of childcare within the family (from elderly people, for instance). In addition, we include two variables that capture social norms (ethnicity and religion) and a range of predetermined proxies for gender attitudes within the household.

\section{Methodological issue: Reverse causality}

As mentioned earlier, there is the potential for causality to work both ways from gender attitudes to work choices and vice versa. In an attempt to mitigate this reverse causality, we have chosen proxies that pre-date the woman's employment as much as possible. The proxies 
we use are the woman's experience of female genital mutilations (FGMs), age at which she first got married, the kind of marriage she is in (polygyny), and her age and education difference with her spouse (Relative Age and Relative Education). Among these, the woman's experience of FGMs is likely to be predetermined because it will have been undertaken when the woman was very young. However, to the extent that it is a measure of conservatism, it might be related in turn to the woman's ethnicity, and our use of this proxy could conflate the two effects. In what follows we will discuss the validity of the other proxies.

Given that women have to navigate their employment decisions within the household to begin with, variables, which reflect their intrahousehold position, are very important to our analysis. To validate our proxies, we need to establish that for most women, the paid work they performed is unlikely to have influenced their choice of partner and therefore is unlikely to have influenced our intrahousehold proxies (Relative Age and Relative Education). In our sample, 76 percent of women only started working after they were 20 years old and with a further 7.5 percent of women working only for their families, more than 83 percent of women were not doing work that might have influenced their choice of partners. In addition, around 69 percent of women were already married by the time they were 20 years old, and 92 percent of women were married by age 25 . Given this, it seems likely that for the vast majority of women in Kenya, the proxies we have chosen for gender attitudes are likely to be predetermined.

The case is further reinforced by the fact that institutions and attitudes are generally "slow moving" (Roland 2004:[please insert page number]), so that any reverse causality might be expected to take longer than a few years (at least on average). Gintis (2001) and Bisin and Verdier (2000) see cultural preferences as being transmitted through socialization, a process that can be expected to take time. To the extent that endogeneity persists in our 
estimations, our results need to be interpreted as correlations and therefore might suffer from bias. Below, we will consider these proxies in more detail.

\title{
Attitudes and institutions
}

\author{
Religion and ethnicity
}

Many religions have traditionally identified certain family structures as ideal, privileging the roles of women as daughters, wives, and mothers over any role they may play outside the home. While the traditional (male breadwinner/female homemaker) view of women's role in society is common to most religions, it seems to be more strictly followed among Muslim and Roman Catholic communities than by Protestant Christian communities in Kenya. It is worth stressing here that the male-breadwinner/ female homemaker model was not always the norm in Africa. In fact, there seems to be an increasing consensus that the shift toward it was at least in part the result of changes during colonialism (Emmanuel Akyeampong and Hippolyte Fofack 2014; Felix Meier zu Selhausen 2014). As with religion, social and cultural norms are often embedded within ethnic groups, which play an important role in Kenya. There are some identifiable differences across ethnic groups in their attitude to women's autonomy and their freedom to undertake work.

\section{Gender attitudes}

In addition to religion and ethnicity, which incorporate attitudes toward a wide range of issues at the community level, we also include proxies that capture household-level gender 
attitudes. These include experience of FGM, the marital status of the woman, and some variables that reflect her relationship with her husband (such as, her intrahousehold bargaining power).

\section{Female genital mutilations}

Female genital mutilations (FGMs) include all surgical procedures involving partial or total removal of the external genitalia or other operations to the female genital organs for cultural or other non-therapeutic reasons (World Health Organization and UNICEF 1997). Existing studies argue that within traditional patrilineal and patrilocal kinship systems, FGMs are practiced as forms of control over women and to reduce a woman's sexual demands on her husband, thus allowing him to have several wives. These practices are enforced through the institution of bride price wherein an uncircumcised girl fetches a lower bride price and therefore represents a threat to the wealth her family can expect on her marriage (Christine J. Walley 1997).

FGMs are associated with more conservative views on gender roles and the traditional perception of women as homemakers. Within this traditional role, work is not common, and therefore this norm is expected to be associated with lower employment of women; and, where women work, they may be more likely to work within rather than outside the house.

In Kenya, FGMs are practiced by various ethnic groups (Somali, Kisii, and Maasai, but also Embu, Kalenjin, and Meru) and involve girls between the ages of 11 and 15 (Hosken 1982[please add this source to the references list]). Table 2 shows that the proportion of women who experienced FGMs in our sample in 2008-9 is highest among the Somali (99 percent), Kisii (93 percent), and Masai (87 percent) groups, followed by the Embu, Kalenjin, 
Meru, and Taita/Taveta groups. FGMs are less common among Kikuyu and Kamba (around 29 percent), and almost nonexistent among Luo and Luhya.

Given the close correlation between ethnicity and women's experience of FGMs, it might not be easy to identify their effects separately. In fact, our results indicate that when ethnicity is included, women's experience of FGMs is not significant. However, in the absence of ethnicity from our model, FGMs become significant as a measure of traditionalism.

(Table 2 here)

\section{Polygyny}

Polygyny, or the practice of men having more than one wife, has long been seen to have an economic rationale for the men who head kin groups in societies where women undertake much of the agricultural labor (Mukesh Eswaran 2014). In these societies, a large family provides both labor and physical security (Boserup 1970). This practice has also been justified as enabling the sharing of duties and chores in the household (Mumbi Mathangani 1995). Given this rationale, it is not clear what impact (if any) it will have on women's labor force participation: while it might increase employment, it may also restrict the woman to working within family enterprises.

Although it cannot legally exist as a union under Kenyan civil law, and is not recognized in the Kenyan Marriage Act, polygyny is allowed in Muslim and customary marriages, which together represent 60 percent of total marriages (OECD [Please add year]). In our sample, 16.8 percent of married women are in a polygynous union. Polygyny is often associated with patriarchal relations between the sexes (Ian M. Timæus and Angela Reynar 1998), and this is shown to be reflected in the nature of decision making. 
We therefore use polygyny as a proxy for traditional gender attitudes. We identify whether the woman is single, married, widowed, divorced, or separated, and, when married, whether she is in a monogynous or polygynous relationship. In general, we might expect married women to face more constraints when entering the labor market. Whether dictated by survival constraints or through genuine choice, single women of all kinds are likely to be able to make decisions independent of men's immediate influence (Naila Kabeer 2005). In addition, while women in polygynous unions face more traditional norms they also have more adult women's support within the household, which might help free up their time for entry into the labor market. Nii-Amoo F. Dodoo (1998) argues that in Kenya, the ultimate effects of the type of marriage on decision making regarding fertility within the family remain unresolved, concluding that women in polygamous marriages may have more decision-making autonomy than anticipated, perhaps afforded by the presence of other wives. Which of these effects dominates is an empirical question. Table 3 indicates that women in polygynous marriages have lower levels of education and marry younger, which also reflects the traditionalism of such unions.

(Table 3 here)

Intra-household gender attitudes

In the sample of married women, we capture the extent of patriarchy experienced by women within the household by including age at first marriage, the age of the woman relative to her spouse, and the woman's education relative to her spouse. These proxies have been widely used in the literature (Seema Vyas and Charlotte Watts 2009); the division of labor (Shannon N. Davis and Theodore N. Greenstein 2004; Martin Browning and Mette Gørtz 2012); and 
other household decisions (Fredrik Carlsson, Peter Martinsson, Ping Qin, and Mattias Sutter 2009; Uma Sarada Kambhampati 2009).

While the woman's absolute education level captures her own abilities, her education relative to her husband (Relative Education) will proxy her ability to bargain with him with respect to her employment (Pradeep Panda and Bina Agarwal 2005). Similarly, there is some evidence that the age at which the woman got married (Marriage Age) as well as the age difference between spouses (Relative Age) might influence the power that women wield within the household (Harriet B. Presser 1975; Mead Cain 1988; Anju Malhotra and Sidney Ruth Shuler 2005). This is particularly true when the age difference reinforces existing gender inequalities, which is often the case. These variables therefore capture the impact of inequalities (in education or maturity, for instance), which may skew the balance of power in the household against the woman.

\section{RESULTS}

We begin by presenting the results for whether a woman undertakes work (Model 1), followed by our results for the type of work a woman performs (Model 2). We use two samples to estimate each of these models - the full sample of women in the dataset and the sample of (once) married women only. We also estimate five versions of each model: Version 1 with only religion and ethnicity; Version 2 with religion and gender attitude variables (FGMs, marital status, and intrahousehold marital variables); Version 3 with ethnicity and gender attitude variables; Version 4, which includes religion, ethnicity, and the other gender attitude variables; and Version 5, which drops both ethnicity and religion and only includes the gender attitude variables. Here, we present only the results for Versions 1 
and 4. The complete set of results is in the supplemental online Appendix. In the rest of this paper, we will only discuss the results for the variables of interest to us - those for sociocultural institutions and gender attitudes. As William H. Greene (2007) recommends, we interpret the size of the marginal effects, but we refer to the significance level of the coefficients.

What determines whether women undertake paid work in Kenya?

To analyze whether women undertake paid work, we estimate a simple probit model. Results are displayed in Table 4.

(Table 4 here)

In Version 1 estimated on the all women sample (first two columns of Table 4), we find that both religion and ethnicity are significant. In particular, Protestant women and women with no religion are more likely to be employed than Catholic women (the baseline category). Muslim women are less likely to be employed than Catholic women. These results also indicate that only Embu and Kisii women have similar or a higher probability of employment as the baseline Kikuyu women. Women from all other ethnic groups are significantly less likely to be employed than Kikuyu women.

In Versions 2 and 3 (see supplemental online Appendix), we dropped Ethnicity and Religion, respectively, but we included proxies for gender attitudes (type of marriage and experience of FGMs). In both cases, religion and ethnicity have a larger impact than in 
Version 1 leading us to conclude that these variables are capturing some of the effect of the excluded variable.

In the all-inclusive Version 4, we see that the signs of the coefficients are the same as in Version 1, and their size is (in most cases) only marginally changed. Thus, even where gender attitude proxies are significant, their impact is not sufficiently large to influence the size of the religion and ethnicity coefficients. The marital status variables are significantly correlated with the probability of paid work. Thus, women in monogynous unions are 0.05 percent less likely to be employed than women who are not married. Divorced women are 11 percent more likely to be employed, and separated women are almost 9 percent more likely to be employed than never-married women.

Dropping all religion and ethnicity variables and looking only at the impact of gender norms in Version 5 (see supplemental online Appendix), we find that there is a significant change in the size of the coefficients leading us to conclude that these variables are picking up at least some of the effect of Religion and Ethnicity.

When we exclude Ethnicity and Religion respectively, we find that the coefficients of marital status increase in magnitude. Finally, experience of FGMs becomes significant and negative only in Versions 2 and 5 when we drop Ethnicity, indicating once again that its impact is largely subsumed in this variable. To the extent that it has an impact, women who are circumcised are less likely to work.

Our results therefore indicate that religion and ethnicity are reasonably good proxies for gender attitudes. However, their significance does not help explain which aspects of these institutions influence women's employment status. Unpacking them to include a woman's experience of FGMs and marital status separately helps to distinguish the specific effects.

In the married women's sample (last two columns of Table 4), once again, the impact of Religion and Ethnicity is similar to that for All Women. In this sample we are able to 
include a wider range of gender attitude variables: Polygyny, FGMs, Relative Age, and Marriage Age (Versions 2 to 5). Women in polygynous marriages are 0.6 percent more likely to work than those in monogynous marriages in Version 4. Similarly, the older and more educated women are relative to their husbands, the more likely they are to be employed. Relative Education has a significant positive effect in all of the models though the size of the coefficient falls to 0.5 percent once Religion is included in Version 4.

In this sample, dropping Religion and Ethnicity makes a small difference to the significance of the individual autonomy variables (Polygyny, Relative Education). In addition, experience of FGMs is never significant leading us to conclude that once women are married, their employment status seems to be correlated to their status relative to their husband rather than to other factors.

Including the level of formal sector employment as a control for the demand for labor, we find that it has a large negative impact on the employment of women in both samples. Thus, increased demand for labor seems to be associated with increased employment for men and to decrease the pressure on women to be employed. For every 1 percent increase in the level of formal employment in the economy, there is a 0.5 percent decrease in the likelihood of married women being employed. The size of this coefficient is larger in the married women's sample, leading us to conclude that this effect is larger when women are in households with male breadwinners.

What influences the type of paid work women choose?

To answer question 2 regarding the choice between different types of paid work for women, we estimate a multinomial logit model. In Table 5, we present the results for versions 1 and 4 
for each of the three paid work choices (work for family, work for outsiders, and work for self), relative to the base category (no work).

Our results (Version 1) indicate that Embu and Kisii women are more likely than Kikuyu women (our base category) to work for the family. Women from all other ethnic groups are generally less likely. We also find that Embu women are not significantly more likely to work for outsiders or for themselves, and Kisii women are the only group significantly more likely than Kikuyu women to work for themselves. Muslim women are less likely to work for outsiders or well for themselves than are Catholic women (our base category). Protestant women are marginally more likely to be self-employed.

(Table 5 here)

When dropping Ethnicity and Religion, respectively (Versions 2 and 3, see supplemental online appendix), the results do not change significantly. Version 4 of the model includes Religion, Ethnicity, and proxies for intra-household gender attitudes: in particular, the woman's experience of FGMs and her marital status. Our results indicate that there is no major change in the effect of Ethnicity and Religion. Marital status is significant: both polygynous and monogynous women are less likely to undertake paid work for outsiders and more likely to work for themselves than women who have never been married (our base category). The magnitude of this effect is larger for polygynous women than for monogynous women. Widows and divorcees are also significantly more likely to be self-employed, whereas women who are separated are more likely both to work for outsiders and for themselves. These results lead us to conclude that single women are most likely to undertake paid work for outsiders and least likely to be self-employed. 
As before, women's experience of FGMs is insignificant in all cases except in Version 2 when we drop ethnicity. Women who are circumcised are more likely to undertake paid work for the family and less likely to work for outsiders or for themselves. Thus, the impact of FGMs is subsumed in the Ethnicity variable. In Version 3 where we drop Religion, we find that the variable capturing experience of FGMs remains insignificant indicating that it is more closely linked to Ethnicity than to Religion.

Finally, we turn to the type of paid work undertaken in the sample of married women (last two columns of Table 5). Our results for Religion and Ethnicity confirm those in earlier estimations. Turning to Version 4, where we include marital status variables and experience of FGMs as well as intrahousehold variables, we find that polygynous women are more likely to be self-employed than monogynous women, though the probability of working for family or outsiders is not significantly different between the two groups.

Our results indicate that the older the woman when she first gets married, the less likely she is to be self-employed. However, Marriage Age is not significantly correlated with working for the family or for outsiders: higher age at first marriage is not associated with increased likelihood of employment (either for family, outsiders, or self). This is a surprising result because age at first marriage is often seen as a measure of how autonomous women are likely to be in their marriages. In fact, from Table 4, we can also see that age at first marriage is not associated with any increase in the probability of employment.

Again, our results indicate that when women are closer to their husbands in age, they are marginally more likely to undertake paid work for outsiders. Though a smaller age gap is not significantly associated with increased work for the family or for self, when women are close to their husbands in education, then we see that they are more likely to be working, either for the family, outsiders or themselves. Thus, we can conclude that the most empowering attribute is education. 
Dropping Ethnicity in Version 2 (see supplemental online appendix) makes very little difference to these results for married women, though it does reveal that women who are circumcised are much more likely to undertake paid work only for their families. Once again, we can conclude that Ethnicity and experience of FGMs are closely correlated, and that the traditionalism associated with FGMs reveals itself in employment only within families.

Overall, our results indicate that Religion and Ethnicity significantly influence women's employment choices in Kenya. Dropping Ethnicity reveals the significance of FGMs indicating that this is a potential proxy for women's autonomy, in particular among unmarried women. In the sample of married women, however, it is the woman's autonomy relative to her husband that is crucial in influencing her work choices. In this sample, therefore, the most important factor is Relative Education rather than the woman being circumcised.

\section{CONCLUSION}

In this paper, we considered the impact of sociocultural institutions on women's labor market participation, focusing on religion and ethnicity as well as the gendered institutions that reflect patriarchal attitudes. While there is significant endogeneity in the extent of traditionalism of communities and decisions made regarding women's paid work, we are unable to correct for this using instrumental variable methods. We therefore try to identify proxies for traditional gender attitudes, which are less likely to suffer reverse causality in the context of Kenya where most women marry young and delay entering the workforce.

Our results lead us to conclude that, in Kenya, both religion and ethnicity are strongly correlated with women's probability of being employed, as is the type of work they do. While 
experience of FGMs is a good proxy for traditionalism, its impact is almost entirely subsumed within ethnicity, and it loses significance when included together with this variable. Marital status is always significantly related to women's employment status, with single women being most likely to work for outsiders and least likely to be self-employed. Polygyny is correlated with an increase in the probability of women working - both for the family and for themselves - but with a decrease in the probability of women working for outsiders. Finally, intrahousehold relativities between spouses are significant: women are more likely to work in households where their education levels are similar to that of their spouses, and they are more likely to work for outsiders in households where the age difference between the spouses is small. Thus, these variables seem to have an empowering effect. Importantly, age at first marriage does not appear to be significant so increasing the statutory age at marriage is unlikely to be helpful.

Our study leads us to conclude that sociocultural institutions and gender attitudes are significantly correlated with women's labor market participation. Given that the latter is significant in influencing women's well-being and that of their families, it is important to ask what might be done to encourage labor market participation or loosen the constraints placed by gender attitudes. Institutions and attitudes are hard to influence in the short run. While economic development may help, some policy action is required. It is worth noting here that women have traditionally tended to undertake paid work in Africa, and the change toward the male-breadwinner model is increasingly being seen as a postcolonial development. Any future changes need to be seen in this context. Thus, labor market policies that tackle women's employment more directly may also help by reestablishing a norm for women's employment and thereby loosening gender attitudes. In Kenya, the ban on FGOs in 2001 is likely to help challenge gender stereotypes within communities. Similarly, more recent 
changes in the marriage law or the reservation of quotas for women in parliament may also help change attitudes in a more durable way.

Giovanna De Giusti

School of Development and Strategic Studies, Maseno University Private Bag Maseno, 40105 Kenya e-mail: Giovanna.degiusti@gmail.com [please insert completed address and email]

Uma Sarada Kambhampati Department of Economics, University of Reading Whiteknights PO Box 218, Reading RG6 6AA, United Kingdom e-mail:les98usk@rdg.ac.uk

[please confirm this information is correct]

\section{NOTES ON CONTRIBUTORS}

Uma Kambhampati is Professor of Economics working on development economics at the University of Reading. She graduated with a PhD from the University of Cambridge in 1992. Uma's research over the years has encompassed a number of areas - applied industrial economics, child labor and schooling, well-being and happiness, and institutions and development. In recent years, she has worked on various aspects of women's autonomy and 
its impact on household welfare.

Giovanna De Giusti graduated with a PhD from the University of Reading in 2012. She worked on women's entrepreneurship and sociocultural institutions in Kenya. Having worked in an experimental laboratory for behavioral studies in Kenya for a year, Giovanna took up a post as Lecturer in Development Studies at the University of Maseno where she continues to work on women's autonomy and entrepreneurship. In addition, she works on international projects relating to the socioeconomic decision-making and institutional aspects of climate change in East Africa.

\section{ACKNOWLEDGMENTS}

We are grateful to seminar participants in the Economics and Geography departments at the University of Reading for comments on an earlier version of this paper. We are also grateful to Sarah Cardey, Augustin Fosu, Bereket Kebede, Wim Naude, Zahra Siddique, and Jackie Wahba for commenting on the work on which this paper is based. 


\section{TABLES}

Table 1 Women's employment status across religions and ethnic groups, KDHS 2008-9

\begin{tabular}{|c|c|c|c|c|c|}
\hline & Not working $(\%)$ & $\begin{array}{l}\text { Working for } \\
\text { family (\%) }\end{array}$ & $\begin{array}{l}\text { Working for } \\
\text { outsider }(\%)\end{array}$ & $\begin{array}{l}\text { Self-employed } \\
(\%)\end{array}$ & Total \\
\hline \multicolumn{6}{|l|}{ Religion } \\
\hline Roman Catholic & 29.7 & 5.0 & 22.2 & 43.1 & 1,224 \\
\hline Protestant/other Christian & 26.4 & 5.0 & 22.8 & 45.8 & 3,873 \\
\hline Muslim & 63.6 & 2.2 & 6.9 & 27.3 & 965 \\
\hline No religion & 29.5 & 2.1 & 7.5 & 61.0 & 146 \\
\hline Other religion & 67.9 & 1.8 & 16.1 & 14.3 & 56 \\
\hline Total & 33.2 & 4.5 & 19.8 & 42.5 & 6,264 \\
\hline
\end{tabular}




\section{Ethnicity}

\begin{tabular}{|c|c|c|c|c|c|}
\hline Kikuyu & 19.8 & 5.4 & 27.9 & 46.9 & 1,192 \\
\hline Embu & 13.9 & 16.5 & 24.4 & 45.2 & 115 \\
\hline Kalenjin & 28.2 & 3.6 & 19.3 & 48.8 & 549 \\
\hline Kamba & 32.3 & 2.4 & 26.3 & 39.0 & 498 \\
\hline Kisii & 16.6 & 12.3 & 18.1 & 53.0 & 349 \\
\hline Luhya & 32.9 & 2.4 & 21.2 & 43.5 & 917 \\
\hline Luo & 24.5 & 7.1 & 19.3 & 49.1 & 787 \\
\hline Masai & 59.8 & 4.9 & 8.5 & 26.8 & 82 \\
\hline Meru & 29.1 & 4.4 & 25.7 & 40.9 & 296 \\
\hline Mijikenda/Swahili & 37.6 & 1.4 & 12.8 & 48.2 & 508 \\
\hline Somali & 80.0 & 1.9 & 3.2 & 14.8 & 466 \\
\hline Taita/Taveta & 45.2 & 1.0 & 25.0 & 28.9 & 104 \\
\hline Other & 53.9 & 2.5 & 11.2 & 32.5 & 403 \\
\hline
\end{tabular}


Source: Calculated using the 2008-9 KDHS

Table 2 FGMs by ethnicity, KDHS 2008-9

\begin{tabular}{|c|c|c|}
\hline Ethnicity & $\begin{array}{l}\text { Number of } \\
\text { women who } \\
\text { have } \\
\text { experienced } \\
\text { FGMs }\end{array}$ & $\begin{array}{l}\text { \% of } \\
\text { women who } \\
\text { have } \\
\text { experienced } \\
\text { FGMs }\end{array}$ \\
\hline Kikuyu & 1,185 & 28.86 \\
\hline Embu & 115 & 55.65 \\
\hline Kalenjin & 548 & 52.01 \\
\hline Kamba & 493 & 29.01 \\
\hline Kisii & 349 & 93.41 \\
\hline
\end{tabular}




\begin{tabular}{|l|r|r|}
\hline Luhya & 890 & 0.34 \\
Luo & 729 & 0.41 \\
Meru & 82 & 86.59 \\
Mijikenda/Swahili & 295 & 42.71 \\
Somali & 410 & 6.34 \\
Taita/Taveta & 465 & 99.35 \\
Other & 102 & 40.20 \\
Total & & 49.45 \\
\end{tabular}

Source: Calculated using the 2008-9 KDHS

Table 3 Selected indicators for women in polygynous and monogynous union, KDHS 2008-9

\begin{tabular}{|l|l|l|l|l|l|l|}
\hline Polygamy & & Level of & Level of & Age relative to \\
education & education relative & Age at marriage & Number of \\
to the partner & & children born \\
\hline
\end{tabular}




\begin{tabular}{|c|c|c|c|c|c|c|}
\hline \multirow{3}{*}{ In monogamous union } & $\mathrm{N}$ & $3,759(83.24 \%)$ & 3,323 & 3,759 & 3,759 & 3,759 \\
\hline & Mean & 1.282 & 0.906 & 19.414 & 0.836 & 3.674 \\
\hline & SD & 0.827 & 0.502 & 4.096 & 0.120 & 2.374 \\
\hline \multirow{3}{*}{ In polygamous union } & $\mathrm{N}$ & $757(16.76 \%)$ & 512 & 757 & 757 & 757 \\
\hline & Mean & 0.777 & 0.810 & 18.317 & 0.762 & 5.005 \\
\hline & SD & 0.732 & 0.666 & 4.487 & 0.159 & 2.665 \\
\hline \multirow{3}{*}{ Total } & $\mathrm{N}$ & $4,516(100 \%)$ & 3,835 & 4,516 & 4,516 & 4,516 \\
\hline & Mean & 1.198 & 0.893 & 19.230 & 0.823 & 3.897 \\
\hline & SD & 0.833 & 0.528 & 4.184 & 0.130 & 2.475 \\
\hline
\end{tabular}

Source: Calculated using the 2008-9 KDHS

Table 4 Determinants of women's employment (marginal effects, s.e.); V1 (religion, ethnicity); and V4 (religion, ethnicity, gender norms)

\begin{tabular}{|l|l|l|}
\hline Variable & All women sample & (Once) Married \\
\hline
\end{tabular}




\begin{tabular}{|c|c|c|c|c|}
\hline & (margins, & s.e.) & $\begin{array}{l}\text { women sal } \\
\text { (margins, }\end{array}$ & $\begin{array}{l}\text { mple } \\
\text { s.e.) }\end{array}$ \\
\hline & V1 & V4 & V1 & V4 \\
\hline Religion=Protestant & $0.028^{*}$ & $0.031^{*}$ & $0.045 * *$ & $0.047 * *$ \\
\hline & 0.046 & 0.047 & 0.050 & 0.058 \\
\hline Religion=Muslim & $-0.119 * * *$ & $-0.119 * * *$ & $-0.111 * * *$ & $-0.077^{*}$ \\
\hline & 0.089 & 0.094 & 0.093 & 0.124 \\
\hline Religion=none & $0.103 * *$ & $0.129 * * *$ & $0.107 * *$ & $0.184 * * *$ \\
\hline & 0.133 & 0.154 & 0.139 & 0.240 \\
\hline Religion=other & $-0.335 * * *$ & $-0.324 * * *$ & $-0.354 * * *$ & $-0.450 * * *$ \\
\hline & 0.203 & 0.234 & 0.218 & 0.279 \\
\hline Ethnicity=Embu & 0.046 & 0.050 & 0.004 & 0.034 \\
\hline & 0.157 & 0.161 & 0.167 & 0.189 \\
\hline Ethnicity=Kalenjin & $-0.054 * *$ & $-0.053 * *$ & $-0.066^{* *}$ & $-0.078 * * *$ \\
\hline
\end{tabular}




\begin{tabular}{|c|c|c|c|c|}
\hline & 0.075 & 0.076 & 0.083 & 0.094 \\
\hline \multirow[t]{2}{*}{ Ethnicity=Kamba } & $-0.112 * * *$ & $-0.104 * * *$ & $-0.112 * * *$ & $-0.138 * * *$ \\
\hline & 0.075 & 0.076 & 0.083 & 0.091 \\
\hline \multirow[t]{2}{*}{ Ethnicity=Kisii } & $0.063 * *$ & $0.070 * *$ & $0.088 * * *$ & $0.076^{* *}$ \\
\hline & 0.095 & 0.102 & 0.111 & 0.126 \\
\hline \multirow[t]{2}{*}{ Ethnicity=Luhya } & $-0.127 * * *$ & $-0.146 * * *$ & $-0.123 * * *$ & $-0.150 * * *$ \\
\hline & 0.066 & 0.070 & 0.072 & 0.086 \\
\hline \multirow[t]{2}{*}{ Ethnicity=Luo } & -0.019 & -0.036 & -0.023 & -0.041 \\
\hline & 0.069 & 0.074 & 0.075 & 0.092 \\
\hline \multirow[t]{2}{*}{ Ethnicity=Maasai } & $-0.344 * * *$ & $-0.351 * * *$ & $-0.388 * * *$ & $-0.386 * * *$ \\
\hline & 0.158 & 0.162 & 0.164 & 0.214 \\
\hline \multirow[t]{2}{*}{ Ethnicity=Meru } & $-0.100 * * *$ & $-0.093 * * *$ & $-0.121 * * *$ & $-0.165 * * *$ \\
\hline & 0.091 & 0.092 & 0.099 & 0.109 \\
\hline Ethnicity=Mijikenda/Swa & -0.042 & -0.030 & $-0.054^{*}$ & -0.060 \\
\hline
\end{tabular}




\begin{tabular}{|c|c|c|c|c|}
\hline hili & 0.096 & 0.105 & 0.102 & 0.131 \\
\hline \multirow[t]{2}{*}{ Ethnicity=Somali } & $-0.438 * * *$ & $-0.416 * * *$ & $-0.481 * * *$ & $-0.491 * * *$ \\
\hline & 0.130 & 0.135 & 0.138 & 0.209 \\
\hline \multirow[t]{2}{*}{ Ethnicity=Taita/Taveta } & $-0.283 * * *$ & $-0.274 * * *$ & $-0.352 * * *$ & $-0.304 * * *$ \\
\hline & 0.135 & 0.138 & 0.151 & 0.167 \\
\hline \multirow[t]{2}{*}{ Ethnicity=other } & $-0.218 * * *$ & $-0.217 * * *$ & $-0.250 * * *$ & $-0.197 * * *$ \\
\hline & 0.094 & 0.098 & 0.101 & 0.134 \\
\hline \multirow{3}{*}{$\begin{array}{l}\text { Rate of formal } \\
\text { employment (at regional } \\
\text { level) }\end{array}$} & $-0.513 * * *$ & $-0.496 * * *$ & $-0.706 * * *$ & $-0.861 * * *$ \\
\hline & & & & \\
\hline & 0.417 & 0.426 & 0.484 & 0.552 \\
\hline \multirow[t]{2}{*}{ In monogamous union } & & $-0.055^{* *}$ & & \\
\hline & & 0.063 & & \\
\hline \multirow[t]{2}{*}{ In polygamous union } & & 0.024 & & $0.055^{* *}$ \\
\hline & & 0.086 & & 0.076 \\
\hline
\end{tabular}




\begin{tabular}{|l|l|l|l|l|}
\hline \multirow{2}{*}{ Divorced } & & $0.113^{* *}$ & & \\
\cline { 2 - 5 } & & 0.172 & & \\
\hline & & $0.088^{* * *}$ & & \\
\hline Separated & & 0.101 & & \\
\hline \multirow{2}{*}{ FGMs } & & -0.021 & & 0.001 \\
\hline Age at (first) marriage & & 0.054 & & 0.067 \\
\hline & & & & -0.003 \\
\hline Relative age & & & & 0.007 \\
\hline \multirow{2}{*}{ (wife/husband) } & & & & $0.122^{*}$ \\
\hline relative education & & & & 0.208 \\
\hline \multirow{2}{*}{ (wife/husband) } & & & & $0.048^{* *}$ \\
\hline & & & & \\
\hline & & & & \\
\hline
\end{tabular}




\begin{tabular}{|l|l|l|l|l|}
\hline 11 & -3352 & -3174 & -2864 & -2021 \\
\hline chi2 & 953.6 & 968.2 & 898.5 & 449.2 \\
\hline r2_p & 0.139 & 0.150 & 0.154 & 0.111 \\
\hline
\end{tabular}

Notes: Values represent marginal effects and s.e. Controls are for: age, age squared, type of place of residence (rural or urban), education level, household size, number of children in various age categories, number of adults over age 60 in household, land and house ownership, and proportion of life lived in the place of residence. Married women's sample relates only to women who have been married once (including married, cohabiting, widowed, divorced, or separated). Standard errors relate to the coefficients not the marginal effects, as Greene (2007) recommends. Robust standard errors; ***, **, and * denote statistical significance at the 1, 5, and 10 percent levels, respectively [Correct?].

Table 5 Determinants of type of work (marginal effects, s.e.); V1 (religion, ethnicity); and V4 (religion, ethnicity, gender norms)

\begin{tabular}{|c|c|c|c|c|c|c|c|c|c|c|c|c|}
\hline \multirow{3}{*}{ Variable } & \multicolumn{4}{|c|}{ Work for family } & \multicolumn{4}{|c|}{ Work for outsider } & \multicolumn{4}{|c|}{ Work for self } \\
\hline & \multicolumn{2}{|c|}{$\begin{array}{l}\text { All women sample } \\
\text { (margins, s.e.) }\end{array}$} & \multicolumn{2}{|c|}{$\begin{array}{l}\text { (Once) Married } \\
\text { women sample } \\
\text { (margins, s.e.) }\end{array}$} & \multicolumn{2}{|c|}{$\begin{array}{l}\text { All women sample } \\
\text { (margins, s.e.) }\end{array}$} & \multicolumn{2}{|c|}{$\begin{array}{l}\text { (Once) Married } \\
\text { women sample } \\
\text { (margins, s.e.) }\end{array}$} & \multicolumn{2}{|c|}{$\begin{array}{l}\text { All women sample } \\
\text { (margins, s.e.) }\end{array}$} & \multicolumn{2}{|c|}{$\begin{array}{l}\text { (Once) Married } \\
\text { women sample } \\
\text { (margins, s.e.) }\end{array}$} \\
\hline & V1 & V4 & V1 & V4 & V1 & V4 & V1 & V4 & V1 & V4 & V1 & V4 \\
\hline
\end{tabular}




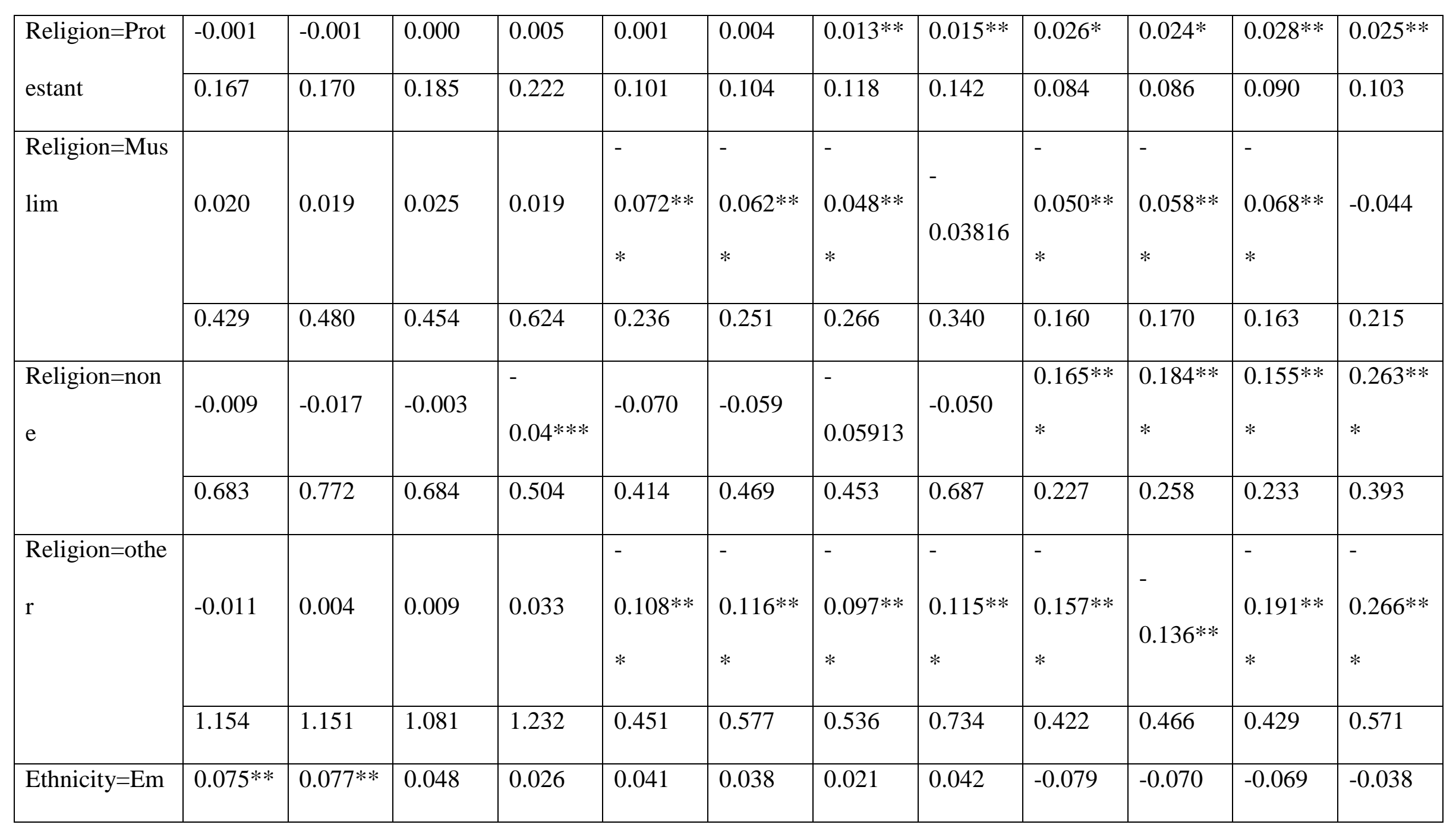




\begin{tabular}{|c|c|c|c|c|c|c|c|c|c|c|c|c|}
\hline \multirow[t]{2}{*}{ bu } & & $*$ & & & & & & & & & & \\
\hline & 0.383 & 0.390 & 0.434 & 0.498 & 0.346 & 0.360 & 0.387 & 0.442 & 0.303 & 0.308 & 0.311 & 0.357 \\
\hline \multirow[t]{2}{*}{$\begin{array}{l}\text { Ethnicity=Kal } \\
\text { enjin }\end{array}$} & $\begin{array}{l}- \\
0.029 * * \\
*\end{array}$ & $\begin{array}{l}- \\
0.030 * * \\
*\end{array}$ & $\begin{array}{l}- \\
0.043 * * \\
*\end{array}$ & $\begin{array}{l}- \\
0.054 * * \\
*\end{array}$ & 0.015 & 0.011 & 0.018 & 0.007 & $0.043^{* *}$ & $\begin{array}{l}- \\
0.036^{* *}\end{array}$ & $\begin{array}{l}- \\
0.047 * * \\
*\end{array}$ & $\begin{array}{l}- \\
0.037 * * \\
*\end{array}$ \\
\hline & 0.287 & 0.288 & 0.334 & 0.436 & 0.171 & 0.176 & 0.203 & 0.242 & 0.136 & 0.138 & 0.148 & 0.166 \\
\hline \multirow[t]{2}{*}{$\begin{array}{l}\text { Ethnicity=Ka } \\
\text { mba }\end{array}$} & $\begin{array}{l}- \\
0.041 * * \\
*\end{array}$ & $\begin{array}{l}- \\
0.040 * * \\
*\end{array}$ & $\begin{array}{l}- \\
0.058 * * \\
*\end{array}$ & $\begin{array}{l}- \\
0.067 * * \\
*\end{array}$ & $0.021 * *$ & 0.030 & 0.051 & 0.054 & $\begin{array}{l}- \\
0.102 * * \\
*\end{array}$ & $\begin{array}{l}- \\
0.105^{* *} \\
*\end{array}$ & $\begin{array}{l}- \\
0.115^{* *} \\
*\end{array}$ & $\begin{array}{l}- \\
0.128 * * \\
*\end{array}$ \\
\hline & 0.352 & 0.357 & 0.445 & 0.521 & 0.162 & 0.167 & 0.186 & 0.212 & 0.139 & 0.140 & 0.149 & 0.163 \\
\hline \multirow[t]{2}{*}{$\begin{array}{l}\text { Ethnicity=Kisi } \\
\text { i }\end{array}$} & $\begin{array}{l}0.056^{* *} \\
*\end{array}$ & $\begin{array}{l}0.058^{* *} \\
*\end{array}$ & $\begin{array}{l}0.057 * * \\
*\end{array}$ & $0.04 * *$ & -0.040 & -0.031 & -0.011 & -0.014 & $0.040 * *$ & $0.038 * *$ & $0.035 * *$ & $0.043 * *$ \\
\hline & 0.269 & 0.301 & 0.306 & 0.366 & 0.216 & 0.238 & 0.253 & 0.300 & 0.177 & 0.188 & 0.210 & 0.235 \\
\hline Ethnicity=Luh & - & - & - & - & - & $0.003 * *$ & $0.021 * *$ & $0.020 * *$ & - & - & - & - \\
\hline
\end{tabular}




\begin{tabular}{|c|c|c|c|c|c|c|c|c|c|c|c|c|}
\hline \multirow[t]{2}{*}{ ya } & $\begin{array}{l}0.043 * * \\
*\end{array}$ & $\begin{array}{l}0.043^{* *} \\
*\end{array}$ & $\begin{array}{l}0.053 * * \\
*\end{array}$ & $0.06 * * *$ & $\begin{array}{l}0.001 * * \\
*\end{array}$ & $*$ & & & $\begin{array}{l}0.088 * * \\
*\end{array}$ & $\begin{array}{l}0.108 * * \\
*\end{array}$ & $\begin{array}{l}0.097 * * \\
*\end{array}$ & $\begin{array}{l}0.113 * * \\
*\end{array}$ \\
\hline & 0.288 & 0.301 & 0.318 & 0.393 & 0.144 & 0.154 & 0.166 & 0.206 & 0.121 & 0.130 & 0.131 & 0.156 \\
\hline \multirow[t]{2}{*}{ Ethnicity=Luo } & 0.006 & $\begin{array}{l}- \\
0.00198\end{array}$ & 0.003 & $-0.019 *$ & -0.015 & 0.001 & -0.006 & 0.017 & -0.019 & $\begin{array}{l}- \\
0.045 * *\end{array}$ & $\begin{array}{l}- \\
0.02916\end{array}$ & $-0.048 *$ \\
\hline & 0.235 & 0.259 & 0.257 & 0.314 & 0.153 & 0.165 & 0.181 & 0.230 & 0.127 & 0.138 & 0.136 & 0.165 \\
\hline \multirow[t]{2}{*}{$\begin{array}{l}\text { Ethnicity=Ma } \\
\text { asai }\end{array}$} & $-0.014^{*}$ & $-0.014^{*}$ & $0.023^{* *}$ & $-0.009 *$ & $\begin{array}{l}- \\
0.060 * * \\
*\end{array}$ & $\begin{array}{l}- \\
0.049 * * \\
*\end{array}$ & $\begin{array}{l}- \\
0.090 * * \\
*\end{array}$ & $\begin{array}{l}- \\
0.084 * * \\
*\end{array}$ & $\begin{array}{l}- \\
0.252 * * \\
*\end{array}$ & $\begin{array}{l}- \\
0.264 * * \\
*\end{array}$ & $\begin{array}{l}- \\
0.273 * * \\
*\end{array}$ & $\begin{array}{l}- \\
0.288 * * \\
*\end{array}$ \\
\hline & 0.609 & 0.622 & 0.639 & 0.676 & 0.461 & 0.473 & 0.626 & 0.818 & 0.302 & 0.311 & 0.298 & 0.398 \\
\hline \multirow[t]{2}{*}{$\begin{array}{l}\text { Ethnicity=Mer } \\
\mathrm{u}\end{array}$} & $\begin{array}{l}- \\
0.025^{* *}\end{array}$ & $0.022^{* *}$ & $0.04 * * *$ & $\begin{array}{l}0.039 * * \\
*\end{array}$ & 0.054 & 0.057 & 0.065 & $0.022 *$ & $\begin{array}{l}0.137 * * \\
*\end{array}$ & $\begin{array}{l}- \\
0.139 * * \\
*\end{array}$ & $\begin{array}{l}- \\
0.154 * * \\
*\end{array}$ & $\begin{array}{l}- \\
0.15^{* * * *}\end{array}$ \\
\hline & 0.367 & 0.369 & 0.399 & 0.420 & 0.195 & 0.198 & 0.225 & 0.269 & 0.169 & 0.169 & 0.179 & 0.192 \\
\hline
\end{tabular}




\begin{tabular}{|c|c|c|c|c|c|c|c|c|c|c|c|c|}
\hline $\begin{array}{l}\text { Ethnicity=Mij } \\
\text { ikenda/Swahil } \\
\text { i }\end{array}$ & $\begin{array}{l}- \\
0.053 * * \\
*\end{array}$ & $\begin{array}{l}- \\
0.051 * * \\
*\end{array}$ & $\begin{array}{l}- \\
0.065 * * \\
*\end{array}$ & $\begin{array}{l}- \\
0.059 * *\end{array}$ & 0.008 & 0.017 & 0.015 & 0.045 & 0.010 & 0.005 & $\begin{array}{l}- \\
0.00119\end{array}$ & -0.048 \\
\hline & 0.565 & 0.633 & 0.638 & 0.800 & 0.232 & 0.254 & 0.260 & 0.326 & 0.172 & 0.189 & 0.179 & 0.229 \\
\hline $\begin{array}{l}\text { Ethnicity=So } \\
\text { mali }\end{array}$ & $\begin{array}{l}- \\
0.047 * * \\
*\end{array}$ & $\begin{array}{l}- \\
0.046^{* *} \\
*\end{array}$ & $\begin{array}{l}- \\
0.067 * * \\
*\end{array}$ & $\begin{array}{l}- \\
0.078 * * \\
*\end{array}$ & $\begin{array}{l}- \\
0.068 * * \\
*\end{array}$ & -0.037 & $\begin{array}{l}- \\
0.051 * * \\
*\end{array}$ & $\begin{array}{l}0.04600 \\
4\end{array}$ & $\begin{array}{l}- \\
0.317 * * \\
*\end{array}$ & $\begin{array}{l}- \\
0.311 * * \\
*\end{array}$ & $\begin{array}{l}- \\
0.353 * * \\
*\end{array}$ & $\begin{array}{l}- \\
0.401 * * \\
*\end{array}$ \\
\hline & 0.646 & 0.685 & 0.675 & 0.719 & 0.382 & $\begin{array}{l}0.406 * * \\
*\end{array}$ & 0.437 & 0.540 & 0.243 & 0.251 & 0.254 & 0.414 \\
\hline $\begin{array}{l}\text { Ethnicity=Tait } \\
\text { a/Taveta }\end{array}$ & $\begin{array}{l}- \\
0.052 * *\end{array}$ & $\begin{array}{l}- \\
0.065^{* *} \\
*\end{array}$ & $\begin{array}{l}- \\
0.076 * * \\
*\end{array}$ & $\begin{array}{l}- \\
0.078 * * \\
*\end{array}$ & $\begin{array}{l}- \\
0.030 * * \\
*\end{array}$ & $\begin{array}{l}- \\
0.017 * * \\
*\end{array}$ & $\begin{array}{l}- \\
0.020 * * \\
*\end{array}$ & $0.005^{* *}$ & $\begin{array}{l}- \\
0.194 * * \\
*\end{array}$ & $\begin{array}{l}- \\
0.183 * * \\
*\end{array}$ & $\begin{array}{l}- \\
0.252 * * \\
*\end{array}$ & $0.23 * * *$ \\
\hline & 1.027 & 0.229 & 0.240 & 0.273 & 0.267 & 0.280 & 0.325 & 0.369 & 0.266 & 0.271 & 0.288 & 0.316 \\
\hline Ethnicity=oth & - & - & - & - & - & - & - & - & - & - & - & - \\
\hline
\end{tabular}




\begin{tabular}{|c|c|c|c|c|c|c|c|c|c|c|c|c|}
\hline \multirow[t]{2}{*}{ er } & $\begin{array}{l}0.035^{* *} \\
*\end{array}$ & $\begin{array}{l}0.036^{* *} \\
*\end{array}$ & $\begin{array}{l}0.052 * * \\
*\end{array}$ & $\begin{array}{l}0.049 * * \\
*\end{array}$ & $\begin{array}{l}0.063 * * \\
*\end{array}$ & $\begin{array}{l}0.049 * * \\
*\end{array}$ & $\begin{array}{l}0.058 * * \\
*\end{array}$ & $\begin{array}{l}0.050^{* *} \\
*\end{array}$ & $\begin{array}{l}0.120^{* *} \\
*\end{array}$ & $\begin{array}{l}0.129 * * \\
*\end{array}$ & $0.14 * * *$ & $\begin{array}{l}0.097 * * \\
*\end{array}$ \\
\hline & 0.478 & 0.503 & 0.538 & 0.666 & 0.249 & 0.256 & 0.291 & 0.383 & 0.171 & 0.178 & 0.178 & 0.232 \\
\hline $\begin{array}{l}\text { Rate of formal } \\
\text { employment } \\
\text { (at regional }\end{array}$ & $\begin{array}{l}- \\
0.096 * *\end{array}$ & $0.073^{* *}$ & $0.21^{* * *}$ & $\begin{array}{l}- \\
0.306 * * \\
*\end{array}$ & 0.325 & 0.250 & 0.245 & $0.148^{*}$ & $\begin{array}{l}- \\
0.870 * * \\
*\end{array}$ & $\begin{array}{l}- \\
0.781 * * \\
*\end{array}$ & $\begin{array}{l}- \\
0.787 * * \\
*\end{array}$ & $\begin{array}{l}- \\
0.741 * * \\
*\end{array}$ \\
\hline level) & 1.968 & 2.020 & 2.499 & 2.718 & 0.855 & 0.881 & 1.039 & 1.211 & 0.807 & 0.827 & 0.901 & 1.023 \\
\hline \multirow[t]{2}{*}{$\begin{array}{l}\text { In } \\
\text { monogamous } \\
\text { union }\end{array}$} & & $\begin{array}{l}- \\
0.019 * *\end{array}$ & & & & $\begin{array}{l}- \\
0.154 * * \\
*\end{array}$ & & & & $0.148 * *$ & & \\
\hline & & 0.220 & & & & 0.135 & & & & 0.127 & & \\
\hline $\begin{array}{l}\text { In } \\
\text { polygamous } \\
\text { union }\end{array}$ & & -0.007 & & 0.004 & & $\begin{array}{l}- \\
0.187 * * \\
*\end{array}$ & & -0.048 & & $\begin{array}{l}0.229 * * \\
*\end{array}$ & & $\begin{array}{l}0.093 * * \\
*\end{array}$ \\
\hline
\end{tabular}




\begin{tabular}{|l|l|l|l|l|l|l|l|l|l|l|l|l|}
\hline & & 0.307 & & 0.278 & & 0.220 & & 0.227 & & 0.162 & & 0.133 \\
\hline Widowed & & -0.008 & & & & -0.094 & & & & $0.173^{* *}$ & $*$ & \\
& & & & & & & & & & & & \\
\hline
\end{tabular}




\begin{tabular}{|l|l|l|l|l|l|l|l|l|l|l|l|}
\hline marriage & & & 0.027 & & & & 0.017 & & & & 0.013 \\
\hline $\begin{array}{l}\text { Relative age } \\
\text { (wife/husband }\end{array}$ & & & & -0.005 & & & & $0.062^{*}$ & & & \\
\hline
\end{tabular}


Notes: Values represent marginal effects and s.e. Controls are for: age, age squared, type of place of residence (rural or urban), education level, household size, number of children in various age categories, number of adults over age 60 in household, land and house ownership, and proportion of life lived in the place of residence. Married women's sample relates only to women who have been married once (including married, cohabiting, widowed, divorced, or separated). Standard errors relate to the coefficients not the marginal effects, as Greene (2007) recommends. Robust standard errors; ***, **, and * denote statistical significance at the 1, 5, and 10 percent levels, respectively. 


\section{REFERENCES}

Adepoju, Aderanti and Christine Oppong. 1994. Gender, Work and Population in SubSaharan Africa. London: James Currey.

Agarwal, Bina. 1997. “'Bargaining'and Gender Relations: Within and Beyond the Household." Feminist Economics 3(1): 1-51.

Akyeampong, Emmanuel and Hippolyte Fofack. 2014. "The Contribution of African Women to Economic Growth and Development in the Pre-Colonial and Colonial Periods: Historical Perspectives and Policy Implications.” Economic History of Developing Regions 29(1): 42-73.

Anderson, Siwan and Mukesh Eswaran. 2009. "What Determines Female Autonomy?

Evidence from Bangladesh.” Journal of Development Economics 90(2): 179-91.

Angrist, Joshua D. and Jörn-Steffen Pischke. 2009. Mostly Harmless Econometrics: An Empiricist's Companion. Princeton, NJ: Princeton University Press.

Audretsch, David B., Werner Bönte, and Jagannadha Pawan Tamvada. 2007. Religion and Entrepreneurship. Centre for Economic Research (CEPR) Discussion Paper 6378.

Basu, Kaushik. 2006. "Gender and Say: a Model of Household Behaviour with Endogenously Determined Balance of Power.” The Economic Journal 116(511): 558-80.

Bisin, Alberto and Thierry Verdier. 2000. “'Beyond the Melting Pot’: Cultural Transmission, Marriage, and the Evolution of Ethnic and Religious Traits." Quarterly Journal of Economics 115(3): 955-88.

Branisa, Boris, Stephan Klasen, and Maria Ziegler. 2010. "Why We Should All Care about Social Institutions Related to Gender Inequality." Paper 50. German Development Economics Conference, Research Committee Development Economics, Hanover. 
Boserup, Esther. 1970. Woman's Role in Economic Development. New York: St. Martin's.

British Council. 2012. “Gender in Nigeria Report 2012: Improving the Lives of Girls and Women in Nigeria, Issues, Policies, Action.” $2^{\text {nd }}$ Edition: British Council Nigeria. Browning, Martin and Mette Gørtz. 2012. "Spending Time and Money within the Household*." Scandinavian Journal of Economics 114(3): 681-704.

Cain, Mead. 1988. "Patriarchal Structure and Demographic Change.” 19-41.[please complete this entry with book/journal title.]

Carlsson, Fredrik, Peter Martinsson, Ping Qin, and Matthias Sutter. 2009. Household Decision Making and the Influence of Spouses' Income, Education, and Communist Party Membership: A Field Experiment in Rural China. 2009-09. Working Papers in Economics and Statistics. [Please provide information on publisher/where this paper may be accessed]

Chen, Martha Alter, Joann Vanek, Francie Lund, James Heintz, Renana Jhabvala, and Christine Bonner. 2005. Progress of the World's Women 2005: Women, Work and Poverty. New York: United Nations Fund for Women.

Chen, Marty and W. I. E. G. O. Network. 2008. "Women Employment in Africa: A Framework for Action.” Second Conference of the Africa Commission.[Please add place and dates of conference]

Davis, Shannon N. and Theodore N. Greenstein. 2004. "Cross- national Variations in the Division of Household Labor." Journal of Marriage and Family 66(5): 1260-71. Dodoo, F. Nii-Amoo. 1998. "Marriage Type and Reproductive Decisions: A Comparative Study in Sub-Saharan Africa.” Journal of Marriage and Family 60(1): 232-42. Duflo, Esther. 2012. "Women Empowerment and Economic Development.” Journal of Economic Literature 50(4): 1051-79. 
Elson, Diane. 1999. "Labor Markets as Gendered Institutions: Equality, Efficiency and Empowerment Issues.” World Development 27(3): 611-27.

Eswaran, Mukesh. 2014. Why Gender Matters in Economics. Princeton, NJ: Princeton University Press..

Farré, Lídia and Francis Vella. 2013. "The Intergenerational Transmission of Gender Role Attitudes and Its Implications for Female Labour Force Participation.” Economica 80(318): 219-47.

Fernández, Raquel. 2013. "Cultural Change as Learning: The Evolution of Female Labor Force Participation over a Century.” American Economic Review 103(1): 472-500.

Fortin, Nicole M. 2005. "Gender Role Attitudes and the Labour-Market Outcomes of Women across OECD Countries." Oxford Review of Economic Policy 21(3): 416-38.

Gintis, Herbert. 2001. "The Simple Analytics of Cultural Stability and Cultural Change." Mimeo, Department of Economics, University of Massachusetts, Amherst..

Goldin, Claudia. 1994. "The U-Shaped Female Labor Force Function in Economic Development and Economic History." Natoinal Bureau of Economic Research (NBER) Working Paper 4707, National Bureau of Economic Research..

Greene, William H. 2007. LIMDEP Version 9.0: Reference Guide. Plainview, NY: Econometric Software..

Hindin, Michelle J. 2000. “Women's Autonomy, Women's Status and Fertility-Related Behavior in Zimbabwe." Population Research and Policy Review 19(3): 255-82. International Labor Organization (ILO). 2008. Global Employment Trends for Women 2008. Geneva: ILO.

Jacoby, Hanan G. 1995. “The Economics of Polygyny in Sub-Saharan Africa: Female Productivity and the Demand for Wives in Côte d'Ivoire.” Journal of Political Economy 103(5): 938-71. 
Jejeebhoy, Shireen J. 2002. “Convergence and Divergence in Spouses' Perspectives on Women's Autonomy in Rural India.” Studies in Family Planning 33(4): 299-308. Jensen, Robert T. 2010. "Economic Opportunities and Gender Differences in Human Capital: Experimental Evidence from India.” National Bureau of Economic Research, Working Paper 16021.

Kabeer, Naila. 2005. "Gender Equality and Women's Empowerment: A Critical Analysis of the Third Millennium Development Goal." Gender and Development 13(1): 13-24.

Kambhampati, Uma Sarada. 2009. "Child Schooling and Work Decisions in India: The Role of Household and Regional Gender Equity.” Feminist Economics 15(4): 77-112.

Kouba, Leonard J. and Judith Muasher. 1985. "Female Circumcision in Africa: An Overview." African Studies Review 28(1): 95-110.

Malhotra, Anju and Sidney Ruth Schuler. 2005. “Women's Empowerment as a Variable in International Development.” In Measuring Empowerment: Cross-Disciplinary Perspectives, edited by Deepa Narayan-Parker, 71-88. Washington, D.C.: World Bank.

Mathangani, Mumbi. 1995. "Women's Rights in Kenya: A Review of Government Policy." Harvard Human Rights Journal 8(1): 179-99.

Morrisson, Christian and Johannes P. Jütting. 2005. "Women's Discrimination in Developing Countries: A New Data Set for Better Policies.” World Development 33(7): 1065-81. Munshi, Kaivan and Mark Rosenzweig. 2006. “Traditional Institutions Meet the Modern World: Caste, Gender, and Schooling Choice in a Globalizing Economy." American Economic Review 96(4): 1225-52.

Organisation for Economic Co-operation and Development (OECD). [Please add year]. "Social Institutions and Gender Index: Gender Equality in Kenya." Gender, Institutions and Development Database (GID-DB) OECD. http://genderindex.org/country/kenya. 
Panda, Pradeep and Bina Agarwal. 2005. "Marital Violence, Human Development and Women's Property Status in India.” World Development 33(5): 823-50.

Presser, Harriet B. 1975. “Age Differences between Spouses: Trends, Patterns, and Social Implications.” American Behavioral Scientist 19(1): 190-205..

Qian, Nancy. 2008. "Missing Women and the Price of Tea in China: The Effect of SexSpecific Earnings on Sex Imbalance.” Quarterly Journal of Economics 123(3): 125185.

Salway, Sarah, Shahana Rahman, and Sonia Jesmin. 2003. “A Profile of Women's Work Participation among the Urban Poor of Dhaka." World Development 31(5): 881-901. Steiber, Nadia and Barbara Haas. 2012. “Advances in Explaining Women's Employment Patterns." Socio-Economic Review 10(2): 343-67.

Timæus, Ian M., and Angela Reynar. 1998. "Polygynists and Their Wives in Sub-Saharan Africa: An Analysis of Five Demographic and Health Surveys.” Population Studies 52(2): 145-62.

Vyas, Seema and Charlotte Watts. 2009. "How Does Economic Empowerment Affect Women's Risk of Intimate Partner Violence in Low and Middle Income Countries? A Systematic Review of Published Evidence.” Journal of International Development 21(5): 577-602.

Walley, Christine J. 1997. “Searching for 'voices': Feminism, Anthropology, and the Global Debate over Female Genital Operations." Cultural Anthropology 12(3): 405-38.

World Health Organization (WHO) and UNICEF. 1997. Female Genital Mutilation: A Joint WHO/UNICEF/UNFPA Statement. Geneva: WHO.

zu Selhausen, Felix Meier 2014. "Missionaries and Female Empowerment in Colonial Uganda: New Evidence from Protestant Marriage Registers, 1880-1945.” Economic History of Developing Regions 29(1): 74-112. 


\section{NOTES}

${ }^{1}$ Of course, it is possible that religion itself is not entirely exogenous, given that an individual's choice of religion and a household's choice to perform FGMs may be correlated with each other and with conservatism more generally (Joshua D. Angrist and Jörn-Steffen Pischke 2009).

${ }^{2}$ Research conducted by the ILO stresses that women's economic autonomy is considered to be highest when they are engaged in wage and salaried work or are employers, lower if they are own-account workers, and lowest when they are unpaid family workers (ILO 2008).

${ }^{3}$ While information on whether her mother was educated and/or worked would have been useful in considering the influence on the women's own attitudes, these data are not made available in the dataset.

${ }^{4}$ The supplemental online Appendix is available under the Supplemental Tab on the publisher's website. 
E-mail: [les98usk@ @rdg.ac.uk]

Contact numbers [+44 7887507560]

Uma S. Kambhampati [Please provide information]

Office: +44 1183785248

Home: +44 2083618782

Cell: +447887507560

Other: NA

Fax: NA

Giovanna De Giusti

Office: NA

Home: NA

Cell: +254700326174

Other: NA

Fax: NA 